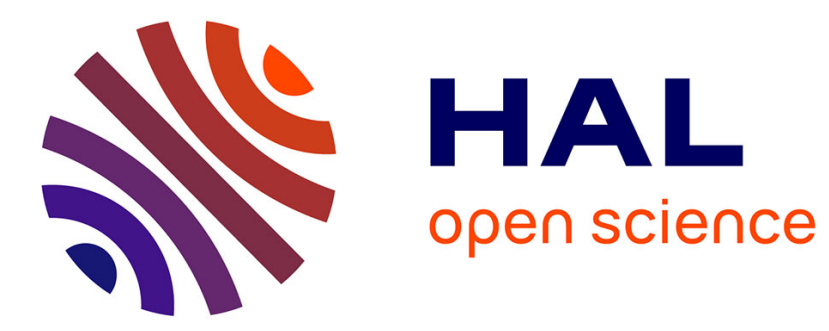

\title{
NOx SCR by urea by Urea: Evidence of the Reactivity of HNCO, Including a Specific Reaction Pathway for NOx Reduction Involving NO + NO 2
}

M. Seneque, F. Can, D. Duprez, X. Courtois

\section{- To cite this version:}

M. Seneque, F. Can, D. Duprez, X. Courtois. NOx SCR by urea by Urea: Evidence of the Reactivity of HNCO, Including a Specific Reaction Pathway for NOx Reduction Involving NO + NO 2. ACS Catalysis, 2016, 6 (7), pp.4064 - 4067. 10.1021/acscatal.6b00785 . hal-01887834

\section{HAL Id: hal-01887834 \\ https://hal.science/hal-01887834}

Submitted on 22 Jan 2021

HAL is a multi-disciplinary open access archive for the deposit and dissemination of scientific research documents, whether they are published or not. The documents may come from teaching and research institutions in France or abroad, or from public or private research centers.
L'archive ouverte pluridisciplinaire HAL, est destinée au dépôt et à la diffusion de documents scientifiques de niveau recherche, publiés ou non, émanant des établissements d'enseignement et de recherche français ou étrangers, des laboratoires publics ou privés. 


\title{
$\mathrm{NO}_{x}$ SCR by urea: evidence of the reactivity of HNCO, includ- ing a specific reaction pathway for NOx reduction involving $\mathrm{NO}+\mathrm{NO}_{2}$.
}

\author{
M. Seneque, F. Can, ${ }^{*}$ D. Duprez and X. Courtois** \\ Institut de Chimie des Milieux et des Matériaux de Poitiers (IC2MP), UMR 7285 CNRS-Université de Poitiers, Bâtiment \\ B27, 4 rue Michel Brunet, TSA 51106, 86073 Poitiers Cedex 9.
}

\begin{abstract}
To treat the NOx emissions from diesel vehicles, NOx selective catalytic reduction (SCR) process by $\mathrm{NH}_{3}$ requires the use of a precursor: an urea aqueous solution. Using an innovative experimental synthetic gas bench adjusted to powdered catalysts and allowing the use of urea or ammonia, the competitive reactivity of the HNCO intermediate species was evidenced. This intermediate species was found to be highly reactive toward $\mathrm{NO}_{2}$, without NOx reduction. During the SCR process, a mix of both $\mathrm{NO}$ and $\mathrm{NO}_{2}$ was evidenced to react with $\mathrm{HNCO}$ and contribute to the NOx reduction efficiency, resulting in an original pathway.
\end{abstract}

KEYWORDS. NOx reduction, SCR, urea, HNCO, reaction pathways.

\section{INTRODUCTION}

Automotive traffic is well-known to be responsible for air pollution, which causes environmental and human health disturbances. Catalytic converters are suitable to purify exhaust gases, but for Diesel engines operating in oxygen excess, $\mathrm{NO}_{\mathrm{x}}$ reduction into $\mathrm{N}_{2}$ is particularly challenging. To meet the severe current standards like Euro 6/VI, the implementation of a specific process, such as the selective catalytic reduction of $\mathrm{NO}_{\mathrm{x}}$ by $\mathrm{NH}_{3}\left(\mathrm{NH}_{3}-\mathrm{SCR}\right)$, is required. The use of an aqueous urea solution as ammonia precursor was adopted by the automotive industry as a safe and operational adaptation of the $\mathrm{NH}_{3}-\mathrm{SCR}$ technology. Ammonia is then obtained by two consecutive reactions: the "urea thermolysis" (Eq. 1) leading to $\mathrm{NH}_{3}$ and $\mathrm{HNCO}$, and the "HNCO hydrolysis" (Eq. 2), leading to the second $\mathrm{NH}_{3}$ molecule to provide the expected amount of reductant.

$$
\begin{aligned}
& \left(\mathrm{NH}_{2}\right) \mathrm{CO}\left(\mathrm{NH}_{2}\right) \rightarrow \mathrm{NH}_{3}+\mathrm{HNCO} \\
& \mathrm{HNCO}+\mathrm{H}_{2} \mathrm{O} \rightarrow \mathrm{NH}_{3}+\mathrm{CO}_{2}
\end{aligned}
$$

Ammonia then reduces $\mathrm{NO}_{\mathrm{x}}$ with different reaction stoichiometry described by Eqs 1 to 4. These reactions are usually denoted as "standard-SCR" (Eq. 3), "fast-SCR" (Eq. 6) and " $\mathrm{NO}_{2}-$ SCR" (Eq. 5 and 6) reactions and involve different $\mathrm{NO}_{2} / \mathrm{NO}_{\mathrm{x}}$ and $\mathrm{NH}_{3} / \mathrm{NO}_{\mathrm{x}}$ ratios. ${ }^{1-5}$

$$
\begin{aligned}
& 4 \mathrm{NH}_{3}+4 \mathrm{NO}+\mathrm{O}_{2} \rightarrow 4 \mathrm{~N}_{2}+6 \mathrm{H}_{2} \mathrm{O} \\
& \mathrm{NH}_{3} / \mathrm{NO}_{\mathrm{x}} \text { stoichiometry: } 1 \\
& 4 \mathrm{NH}_{3}+2 \mathrm{NO}+2 \mathrm{NO}_{2} \rightarrow 4 \mathrm{~N}_{2}+6 \mathrm{H}_{2} \mathrm{O} \\
& \mathrm{NH}_{3} / \mathrm{NO}_{\mathrm{x}} \text { stoichiometry: } 1 \\
& 4 \mathrm{NH}_{3}+3 \mathrm{NO}_{2} \rightarrow 3.5 \mathrm{~N}_{2}+6 \mathrm{H}_{2} \mathrm{O} \\
& \mathrm{NH}_{3} / \mathrm{NO}_{\mathrm{x}} \text { stoichiometry: } 1.33 \\
& 4 \mathrm{NH}_{3}+2 \mathrm{NO}_{2}+\mathrm{O}_{2} \rightarrow 3 \mathrm{~N}_{2}+6 \mathrm{H}_{2} \mathrm{O} \\
& \mathrm{NH}_{3} / \mathrm{NO}_{\mathrm{x}} \text { stoichiometry: } 2
\end{aligned}
$$

Unfortunately, incomplete urea decomposition may occur ${ }^{6}$ thus entailing a mixture of $\mathrm{NH}_{3}, \mathrm{HNCO}$ and urea on the SCR catalyst. The HNCO intermediate exhibits high reactivity and reacts not only with $\mathrm{H}_{2} \mathrm{O}$ to produce $\mathrm{NH}_{3}$, but also with condensed urea, leading to formation of solid deposits for $\mathrm{T} \leq 180^{\circ} \mathrm{C}$, as biuret (Eq. 7$)^{7}$

$$
\left(\mathrm{NH}_{2}\right) \mathrm{CO}\left(\mathrm{NH}_{2}\right)+\mathrm{HNCO} \rightarrow\left(\mathrm{NH}_{2}\right) \mathrm{CO}(\mathrm{NH}) \mathrm{CO}\left(\mathrm{NH}_{2}\right)
$$

In addition, it was recently demonstrated that $\mathrm{HNCO}$ appears more reactive toward $\mathrm{O}_{2}$ than $\mathrm{NH}_{3}$. Selective catalytic oxidation (SCO) experiments show a reductant oxidation at $300^{\circ} \mathrm{C}$ of about $30 \%$ for Urea-SCO compared to $8 \%$ for $\mathrm{NH}_{3}-\mathrm{SCO}{ }^{8}$ These undesired side-reactions can lead to the deactivation of the catalyst by poisoning, and also induce an undesired overconsumption of the injected reductant. To avoid these drawbacks, deeper understanding of Urea-SCR pathways in urea availability and ammonia release is of the most interest. In fact, significant efforts have been undertaken to describe total urea decomposition reaction ${ }^{3,7,9}$ assuming that $\mathrm{NO}_{\mathrm{x}}$ reduction is thereafter correlated to $\mathrm{NH}_{3}$ yield and follows similar pathways than those demonstrated when ammonia is directly used as reductant. The first step assumed for $\mathrm{NH}_{3}-\mathrm{NO} / \mathrm{NO}_{2}-\mathrm{O}_{2}$ gas mixture over exchanged zeolites and oxides-based catalysts is the $\mathrm{NO}_{2}$ disproportion to nitrous and nitric acid (Eq. 8) followed by the nitric acid reduction by NO (Eq.9) ${ }^{3}$, leading to the overall reaction (10).

$$
\begin{aligned}
& 2 \mathrm{NO}_{2}+\mathrm{H}_{2} \mathrm{O} \leftrightarrows \mathrm{HONO}+\mathrm{HNO}_{3} \\
& \mathrm{HNO}_{3}+\mathrm{NO} \leftrightarrows \mathrm{HONO}+\mathrm{NO}_{2} \\
& \mathrm{NO}+\mathrm{NO}_{2}+\mathrm{H}_{2} \mathrm{O} \leftrightarrows 2 \mathrm{HONO}
\end{aligned}
$$

HONO is therefore a key intermediate which can react with $\mathrm{NH}_{3}$ to form ammonium nitrite which easily decompose into $\mathrm{N}_{2}$ (Eq. 11). ${ }^{10-12}$

$$
\mathrm{NH}_{3}+\mathrm{HONO} \rightarrow \mathrm{NH}_{4} \mathrm{NO}_{2} \rightarrow \mathrm{N}_{2}+2 \mathrm{H}_{2} \mathrm{O}
$$


The combination of reactions (10) and (11) corresponds to Eq. (4), i.e. the "fast-SCR" stoichiometry.

Finally, the urea decomposition to ammonia and side-reactions are well known, as well as the mechanism of the NOx reduction by $\mathrm{NH}_{3}$. However, detailed pathways in the $\mathrm{NO}_{x} \mathrm{SCR}$ process by urea or its by-products remains poorly documented. We present herein the behavior of an acidic zirconia based catalyst (denoted aZr, provided by Solvay ${ }^{13}$ ) in Urea-SCR. The direct comparison of $\mathrm{NH}_{3}$ or urea as reductant allow us to point out different behaviors, and the variation of the $\left(\mathrm{NO} / \mathrm{NO}_{2}\right)$ inlet ratio is use to address the role of $\mathrm{NO}_{2}$ in the involved reactions during the $\mathrm{NO}_{\mathrm{x}} \mathrm{SCR}$ process using urea.

\section{EXPERIMENTAL}

A synthetic gas bench adjusted to powdered catalysts allowing direct comparison of $\mathrm{NH}_{3}-\mathrm{SCR}$ and Urea-SCR reactions at the laboratory scale was recently developed to easily act on the experimental parameters and directly compare the use of both reductants, urea or ammonia. ${ }^{8}$ The experimental set-up for catalytic test is detailed in the Supporting Information (SI) file (Figure S1). Two urea residence times (elapsed time for the gaseous mixture between urea injection zone and the catalytic bed) were examined: $5.2 \mathrm{~s}$ and $4.0 \mathrm{~s}$. They are well away from the requirements encountered in real conditions (order of magnitude: one second) but sufficiently low to observe differences in the pathways related to the use of urea over the studied catalyst. Note that without catalyst, the complete urea decomposition into ammonia is achieved at the analyzer level (all pipes of the apparatus are heated at $200^{\circ} \mathrm{C}$, the residence time between urea injection and analyzer is around $34 \mathrm{~s}$ ). Consequently, only $\mathrm{NH}_{3}$ is detected (HNCO is never observed) and the outlet urea concentration is expressed as equivalent ammonia, and denoted " $\mathrm{NH}_{3(\mathrm{eq})}$ ". The $\mathrm{NO}_{2}$ to $\mathrm{NO}_{\mathrm{x}}$ inlet ratios were fixed at $0,0.5,0.7$ and 1 (Table S1). The compositions of the feed gas and effluent stream were monitored continuously using online MKS Multigas infrared analyzer for $\mathrm{NO}, \mathrm{NO}_{2}, \mathrm{~N}_{2} \mathrm{O}, \mathrm{HNCO}, \mathrm{NH}_{3}, \mathrm{CO}, \mathrm{CO}_{2}$ and $\mathrm{H}_{2} \mathrm{O}$.

\section{RESULTS AND DISCUSSION}

Figure 1 reports the effect of the urea residence time on the $\mathrm{NO}_{\mathrm{x}}$ conversion for various $\mathrm{NO}_{2} / \mathrm{NO}_{\mathrm{x}}$ inlet ratios. For the longer urea residence time $\left(t_{R}=5.2 \mathrm{~s}\right)$, results are similar than those obtained with gaseous $\mathrm{NH}_{3}$ as reductant, proving that the availability of $\mathrm{NH}_{3}$ is then satisfactory (Figure $\mathrm{S} 2$, SI file).

When the urea residence time is decreased to $4.0 \mathrm{~s}$, a drop in $\mathrm{NO}_{\mathrm{x}}$ conversion is clearly denoted (Figure 1). The most significant loss of activity is observed for the standard SCR condition, when only $\mathrm{NO}$ is introduced as $\mathrm{NO}_{\mathrm{x}}$ (Figure $1 \mathrm{~A}, \mathrm{NO}_{2} / \mathrm{NO}_{\mathrm{x}}=0$ ). It was previously evidenced that the observed activity loss is not attributed to a catalyst surface deactivation caused by deposit formation (Figure S3, SI file) but to a lack of available $\mathrm{NH}_{3(\mathrm{eq})}$ due to an incomplete HNCO hydrolysis, that induces the presence of $\mathrm{HNCO}$ at the aZr catalyst level. ${ }^{8}$

Increasing the proportion of $\mathrm{NO}_{2}$ in the reaction mixture (Figure $1 \mathrm{~B}$ and $1 \mathrm{C}, \mathrm{NO}_{2} / \mathrm{NO}_{\mathrm{x}}=0.5$ and 0.7 , respectively) leads to reduce the drop of deNO$_{x}$ activity for urea residence time of $4.0 \mathrm{~s}$ compared to $\mathrm{NOx}$ reduction in standard condition $\left(\mathrm{NO}_{2} / \mathrm{NO}_{\mathrm{x}}=0\right.$, Figure 1A). These results seems to indicate that the presence of $\mathrm{NO}_{2}$ interferes in the reductant availability and/or in $\mathrm{NO}_{\mathrm{x}}$ reduction reactions involved in Urea-SCR. To highlight the specific reactivity of $\mathrm{NO}_{2}$ in $\mathrm{NO}_{\mathrm{x}}$ reduction mechanism, Urea-SCR and $\mathrm{NH}_{3}$-SCR experiments were especially carried out in $\mathrm{NO}_{2}$-only condition $\left(\mathrm{NO}_{2} / \mathrm{NO}_{\mathrm{x}}\right.$ inlet $\left.=1\right)$.
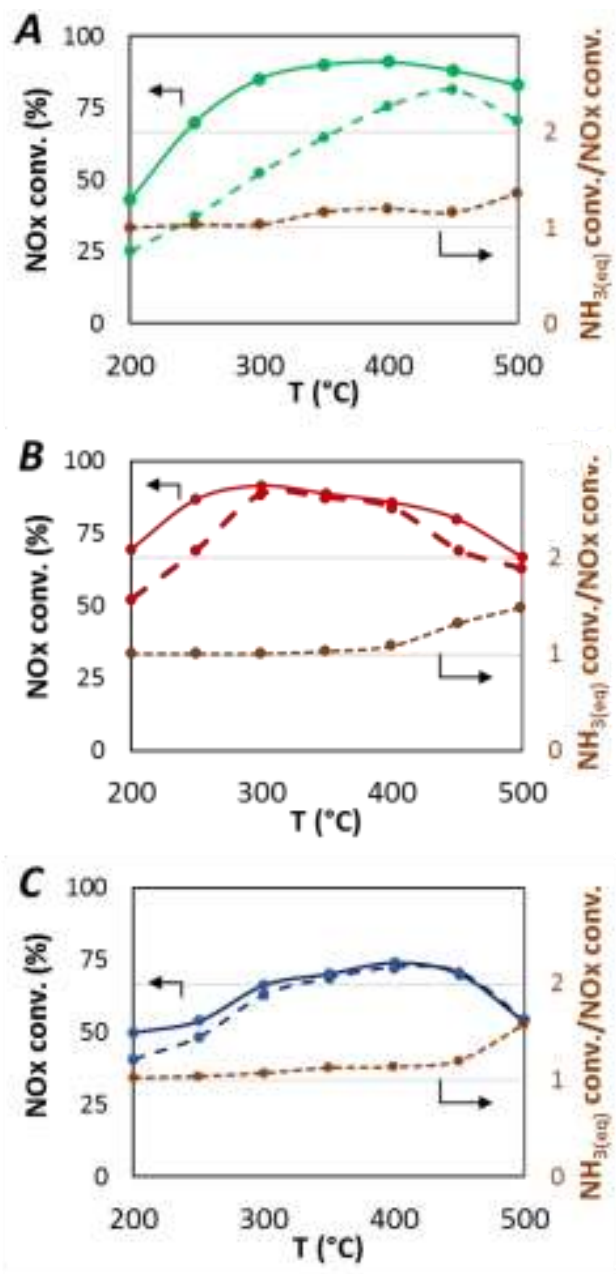

Figure 1. Effect of urea residence time on $\mathrm{NO}_{\mathrm{x}}$ conversion (full line: $t_{R}=5.2 \mathrm{~s}$; dotted line: $\mathrm{t}_{\mathrm{R}}=4.0 \mathrm{~s}$ ) and $\mathrm{NH}_{3(\mathrm{eq})} / \mathrm{NO}_{\mathrm{x}}$ conversion ratio at $t_{R}=4.0 \mathrm{~s}$ for various $\mathrm{NO}_{2} / \mathrm{NOx}$ inlet ratio over $\mathrm{aZr}$ catalyst. GHSV $=160000 \mathrm{~h}^{-1} ; \mathrm{NOx}=400 \mathrm{ppm}$, urea $=200$ ppm, $\mathrm{H}_{2} \mathrm{O}=8 \%, \mathrm{O}_{2}=10 \%, \mathrm{CO}_{2}=10 \%$.

$\mathrm{A}: \mathrm{NO}_{2} / \mathrm{NOx}=0 ; \mathrm{B}: \mathrm{NO}_{2} / \mathrm{NOx}=0.5 ; \mathrm{C}: \mathrm{NO}_{2} / \mathrm{NOx}=0.7$

\subsection{Specific Reactivity of $\mathrm{HNCO}$ with $\mathrm{NO}_{2}$}

In order to study the reactivity of $\mathrm{HNCO}$ with $\mathrm{NO}_{2}$, specific SCR tests were performed with $\mathrm{NO}_{2}$ only in the inlet gases $\left(\mathrm{NO}_{2} / \mathrm{NO}_{\mathrm{x}}\right)_{\text {inlet ratio }}=1$. For $\mathrm{NH}_{3}-\mathrm{SCR}$, results reported in Figure $2 \mathrm{~A}$ show that ammonia and NOx conversions are the same until $350^{\circ} \mathrm{C}$, with conversion rates between 30 and $50 \%$. For higher temperatures, $\mathrm{NH}_{3}$ oxidation was clearly evidenced. ${ }^{5}$ Additionally, there is nearly no $\mathrm{NO}$ emission when gaseous $\mathrm{NH}_{3}$ is used as reductant agent.

To the opposite, concerning urea-SCR experiments, it clearly appears from Figure 2B that reductant is surprisingly fully converted in the whole studied temperature range. At the same time, NO is produced in substantial amounts (around $40 \mathrm{ppm}$ ).

These divergent results between urea and ammonia confirm an incomplete urea hydrolysis, in agreement with SCO experiments previously reported in Ref. 8. The urea by-product, assumed to be $\mathrm{HNCO}$, also exhibits a particularly high reactivity with $\mathrm{NO}_{2}$ (Figure $2 \mathrm{~B}$ ) in the $200-500^{\circ} \mathrm{C}$ temperature range. Taking into account the outlet $\mathrm{NO}, \mathrm{NO}_{2}$ and $\mathrm{NH}_{3}$ concentrations, the contribution of $\mathrm{O}_{2}$ as co-oxidant agent has to be considered in addition to nitrogen dioxide to fully convert the reductant 
agent. Note that the beneficial effect of $\mathrm{NO}_{2}$ on the $\mathrm{HNCO}$ oxidation rate by $\mathrm{O}_{2}$ was previously reported by Takeda and Iwamoto over exchanged $\mathrm{Cu}$ zeolite. ${ }^{14}$ The stoichiometry and possible reaction pathways involving urea by-products, $\mathrm{NO}_{2}, \mathrm{NO}$ and $\mathrm{O}_{2}$ over aZr catalyst are detailed in the SI file. At $200^{\circ} \mathrm{C}$, the global stoichiometry respecting the observed results is close to $\mathrm{Eq}(12)\left(\mathrm{N}^{-\mathrm{III}}\right.$ species correspond to the reductant species from urea, coefficient for $\mathrm{H}_{2} \mathrm{O}$ and $\mathrm{CO}_{2}$ are calculated from urea injection).

$$
9 \mathrm{~N}^{-\mathrm{III}}+3 \mathrm{NO}_{2}+17 / 4 \mathrm{O}_{2} \rightarrow \mathrm{NO}+11 / 2 \mathrm{~N}_{2}+9 \mathrm{H}_{2} \mathrm{O}+9 / 2 \mathrm{CO}_{2}
$$

This particular reactivity between $\mathrm{HNCO}$ and $\mathrm{NO}_{2}$ was also expected to occur for $\mathrm{NO}_{2} / \mathrm{NO}_{\mathrm{x}}$ inlet ratio of 0.5 and 0.7 . The behaviour of the reductant during SCR reactions can be monitored by the $\mathrm{NH}_{3(\mathrm{eq})} / \mathrm{NO}_{\mathrm{x}}$ conversion ratio. It appears from Figure 1 that this ratio remains close to 1 in the $200-400^{\circ} \mathrm{C}$ temperature range, which induces a standard or fast SCR stoichiometry (Eq. 3 and 4). An over-consumption of reductant is denoted only for temperature higher than $400^{\circ} \mathrm{C}$, whatever the $\mathrm{NO}_{2} / \mathrm{NO}_{\mathrm{x}}$ inlet ratio. It is commonly assigned to a reductant reactivity with $\mathrm{O}_{2}{ }^{5,8}$

Finally, HNCO intermediate species could react easily with $\mathrm{NO}_{2}$ or $\mathrm{NO}_{2}+\mathrm{O}_{2}$. However, these results do not explain how $\mathrm{NO}_{2}$ acts in the urea-SCR mechanism for $\mathrm{NO}_{\mathrm{x}}$ reduction, since the effect of shortened urea residence time in $\mathrm{NO}_{\mathrm{x}}$ conversion dissipates together with the increase of $\mathrm{NO}_{2}$ in the inlet gas mixture, without over consumption of reductant (Figure 1).

\subsection{Reactivity of $\mathrm{HNCO}$ with $\mathrm{NO}$ versus $\left(\mathrm{NO}+\mathrm{NO}_{2}\right)$}

For urea-SCR, a $\mathrm{NO}_{\mathrm{x}}$ conversion of $70 \%$ is denoted at $250^{\circ} \mathrm{C}$ in fast-SCR condition (Figure 1B), showing that $70 \%$ of the $\mathrm{NH}_{3(\mathrm{eq})}$ reductant is converted at $\mathrm{t}_{\mathrm{R}}=4.0 \mathrm{~s}\left(\mathrm{NH}_{3(\mathrm{eq})} / \mathrm{NO}_{\mathrm{x}}=1\right.$ in inlet and outlet gas mixtures).

To the opposite, only $37 \%$ of $\mathrm{NO}_{\mathrm{x}}$ conversion is achieved in standard condition $\left(t_{R}=4.0 \mathrm{~s}\right)$ whereas a maximum of around $70 \%$ could be reached in the case of an optimal ammonia availability, as illustrated in Figure $1 \mathrm{~A}$ for $t_{R}=5.2 \mathrm{~s}$. Consequently, the drop in deNO$_{x}$ efficiency observed in standard-SCR condition for shortened urea residence time is not only related to a lack of $\mathrm{NH}_{3(\mathrm{eq})}$ due to an incomplete $\mathrm{HNCO}$ hydrolysis, but also to a defective activation of $\mathrm{HNCO}$ reductant by NO. Additionally, it is evidenced that the presence of both $\mathrm{NO}$ and $\mathrm{NO}_{2}$ beneficially interfere at the catalytic level with urea by-products, assumed to be HNCO, allowing a better use of the reductant species supported by a higher $\operatorname{deNO}_{x}$ efficiency. This NOx reduction enhancement can be described by reaction (13).

$$
2 \mathrm{HNCO}+\mathrm{NO}+\mathrm{NO}_{2} \rightarrow 2 \mathrm{~N}_{2}+\mathrm{H}_{2} \mathrm{O}+2 \mathrm{CO}_{2}
$$

In fact, in the established mechanism for $\mathrm{NO}_{\mathrm{x}} \mathrm{SCR}$ by $\mathrm{NH}_{3}$, as well as in reactional pathways mentioned when alcohols or hydrocarbon are used as reductant ${ }^{15,16}$, the final step of deNO chemistry in lean media is the formation of $\mathrm{N}_{2}$ by decomposition of ammonium nitrite (Eq. 11). It systematically involves the HONO intermediate species, which is formed by the overall reaction (10) respecting an optimal $\mathrm{NO}: \mathrm{NO}_{2}$ balance of $1: 1$, as for the "fast" SCR stoichiometry (Eq. 4). Consequently, a similar route in which HONO intervenes is postulated in the $\mathrm{NO}_{\mathrm{x}}$ reduction with urea to support the observed experimental results (Figure 1). It is proposed that isocyanic acid reacts with nitrous acid to yield nitrogen, as described in Eq (14), in which HONO is produced by reaction (10).

$$
\mathrm{HNCO}+\mathrm{HONO} \rightarrow \mathrm{N}_{2}+\mathrm{H}_{2} \mathrm{O}+\mathrm{CO}_{2}
$$

The sum of reactions (10) and (14, twice) corresponds to the global equation (13) of the "HNCO-SCR" route.
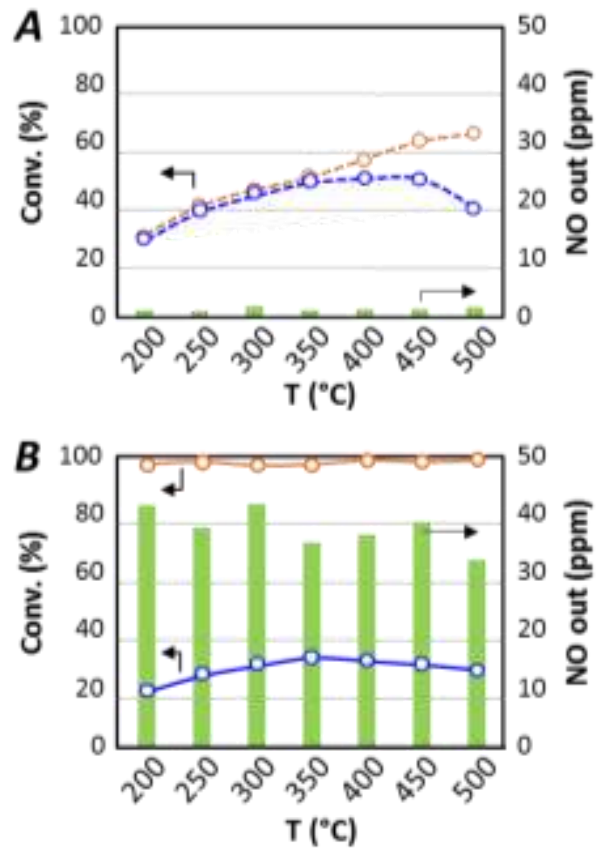

Figure 2. $\mathrm{NO}_{2}$-only $\mathrm{SCR}\left(\mathrm{NO}_{2} / \mathrm{NO}_{\mathrm{x}}=1\right)$ over aZr catalyst with (A): $\mathrm{NH}_{3}$; (B): urea. (-): $\mathrm{NO}_{\mathrm{x}}$ conversion; (-): $\mathrm{NH}_{3(\mathrm{eq})}$ conversion; $(\square)$ : NO out emission. GHSV $=160000 \mathrm{~h}^{-1} ; \mathrm{NO}_{2}=$ $400 \mathrm{ppm}, \mathrm{NH}_{3}=400 \mathrm{ppm}$ or urea $=200 \mathrm{ppm}, \mathrm{H}_{2} \mathrm{O}=8 \%, \mathrm{O}_{2}=$ $10 \%, \mathrm{CO}_{2}=10 \%$.

\section{CONCLUSION}

This work evidenced the high reactivity of HNCO toward the gas feed constituents in the NOx SCR by urea process. The expected HNCO hydrolysis to yield ammonia can compete with other reactions, like oxidation by $\mathrm{O}_{2}$ and especially $\mathrm{NO}_{2}$, even if these oxidation reactions appear negligible during the SCR process over the studied catalyst. This study also evidences a new "HNCO-SCR" route involving both $\mathrm{NO}$ and $\mathrm{NO}_{2}$, probably via the formation of HONO, which is commonly proposed as intermediate species in $\mathrm{NO}_{\mathrm{x}}$ reduction mechanisms. Finally, the various competitive reactions regarding $\mathrm{HNCO}$ in the urea SCR process are highlighted in Scheme 1.

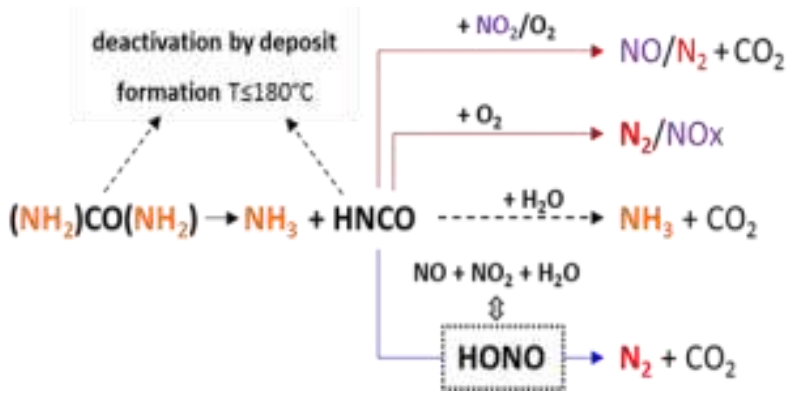

Scheme 1. Proposal of HNCO competitive reactivity for Urea-SCR with shortened urea residence time. 


\section{ASSOCIATED CONTENT}

Supporting Information.

- Experimental Urea-SCR catalytic apparatus and test protocol.

- Effect of reductant agent, $\mathrm{NH}_{3}$ or Urea $\left(\mathrm{t}_{\mathrm{R}}=5.2 \mathrm{~s}\right)$, depending on the $\left(\mathrm{NO}_{2} / \mathrm{NOx}\right)$ inlet ratio.

- Characterization by TPD/TPO of the adsorbed species depending on the injected reductant.

- Reductant consumption in $\mathrm{NO}_{2}$-only Urea-SCR condition.

This material is available free of charge via the Internet at http://pubs.acs.org.

\section{AUTHOR INFORMATION}

\section{Corresponding Author}

To whom correspondence should be addressed

*xavier.courtois@univ-poitiers.fr

* fabien.can@univ-poitiers.fr

\section{Author Contributions}

The manuscript was written through contributions of all authors.

\section{ACKNOWLEDGMENT}

The authors gratefully acknowledge the French National Agency for Research for its financial support (UreeNOx Project, Ref. ANR-11-VPTT-002).

\section{REFERENCES}

(1) Sullivan, J.A., Doherty, J.A., Appl. Catal. B. 2005, 55, 185-194.

(2) Lietti, L., Nova, I., Forzatti, P., J. Catal. 2008, 257, 270-282.

(3) Koebel, M., Elsener, M., Madia, G., Ind. Eng. Chem. Res., 2001, 40, 52-59.

(4) Kato, A., Matsuda, S., Kamo, T., Nakajima, F., Kuroda, H., Narita, T., J. Phys. Chem. 1981, 85, 4099-4102.

(5) Can, F., Berland, S., Royer, S., Courtois, X., Duprez, D., ACS Catal., 2013, 3, 1120-1132.

(6) Koebel, M., Strutz, E.O., Ind. Eng. Chem. Res. 2003, 42, $2093-$ 2100

(7) Bernhard, A.M., Peitz, D., Elsener, M., Wokaun, A., Kröcher, O., Appl. Catal. B. 2012, 115-116, 129-137.

(8) Seneque, M., Can, F., Duprez, D., Courtois X., Catalysts, 2015, $5,1535-1553$.

(9) Bernhard, A.M., Peitz, D., Elsener, M., Schildhauer, T., Kröcher, O., Catal. Sci. Technol., 2013, 3, 942-951.

(10) Grossale, A., Nova, I., Tronconi, E., Chatterjee, D., Weibel,M., Top. Catal., 2009, 52, 1837-1841.

(11) Nova, I., Ciardelli, C.,Tronconi, E., Chatterjee, D., Bandl-Konrad, B., Catal. Today, 2006, 114, 3-12.

(12) Yeom, Y.H., Henao, J., Li, M.J., Sachtler, W.M.H., Weitz, E., J. Catal. 2005, 231, 181-193.

(13) Verdier, S., Rohart, E., Bradshaw, H., Harris, D., SAE Technical Paper 2008, 2008-01-1022

(14) Takeda, T., Iwamoto, M., Catal. Letters, 1996, 38, 21-25

(15) Y.H. Yeom, M. Li, A. Savara, W.M.H. Sachtler, E. Weitz, J. Catal, 2006, 238, 100-110.

(16) Gorce, O., Baudin, F., Thomas, C., Da Costa, P., Djéga-Mariadassou, G., Appl. Catal. B., 2004, 54, 69-84. 